\title{
A STUDY ON STATUTORY PROVISIONS FOR CONSTRUCTION SAFETY IN INDIA
}

\author{
DR.P.SIVAPRAKASH ${ }^{1}$, DR.S.KANCHANA ${ }^{2}$
}

\begin{abstract}
There are about 8.5 million workers employed in the construction sector in India. Construction workers constitute a major portion of the unorganized labour and are characterized by their casual nature of employment, temporary relationship with the employer, prolonged and uncertain working hours, lack of safety and health measures, and inadequacy of basic amenities and welfare facilities. There are many legislation clauses providing safeguards for contract workers in India. Construction safety has been made legally enforceable after the enactment of The Building and Other Construction Workers (Regulation of Employment and Conditions of Service) Act in 1996 and the Central Rules in 1998. This paper details various statutory provisions for construction safety in India with specific reference to the BOCW Act, Central Rules, and State Rules.
\end{abstract}

Keywords: BOCW Act, Construction Safety, Hazards, Legislation.

\footnotetext{
${ }^{1}$ Asso. Prof.,Ph.D., Eng.,A.S.L.Pauls College of Engineering and Technology, Coimbatore - 641032, India, drpsivaprakash@gmail.com

${ }^{2}$ Asso.Prof.,Ph.D., Eng.,RVS Technical Campus - Coimbatore, Coimbatore - 641402, India, kash10304@gmail.com
} 


\section{INTRODUCTION}

The sustainability of the construction process and its improvement largely depends on the health and safety of the construction workers [1]. The construction industry of India is an important indicator of development as it creates investment opportunities across various related sectors. The sector is labourintensive and, including indirect jobs, provides employment to more than 35 million people [2]. Health and safety management practices in the construction process can be improvised at various levels. Different construction stages incorporate the role of clients, project managers, architects, engineers, contractors, subcontractors, suppliers, and manufacturers [3]. Efforts have been made to address this problem, but the results have been far from satisfactory as construction accidents continue to dominate the industry. Despite the programs implemented by government authorities and measures introduced by companies themselves, the number of construction accidents still remains alarmingly high. It is highly unsatisfactory that the implementation of health and safety provisions in construction has not resulted in any commensurate improvement in the industry. The construction industry is in need of more effective approaches involving better mechanisms to face industry challenges [4]. This paper provides insight in to the various statutory provisions for construction safety in India with specific reference to the BOCW Act, Central Rules, and State Rules.

\section{OBJECTIVES OF THE STUDY}

The objectives considered for this study are:

- To regulate the employment and conditions of service of construction workers.

- To provide safety, health, and welfare measures and for other matters connected therewith.

\section{LITERATURE REVIEW}

The literature survey reviews the safety aspects among workers thereby providing a safe working environment to the construction workers. According to Charles Y.J. Cheah, there is a high degree of consensus on the three most important parties in assuming safety responsibilities: (i) workers who execute the physical tasks, (ii) contractors who employ the workers, and (iii) government who sets up 
the legislative framework which governs S\&H policies and practices. There is, however, a wider disparity of views on those safety responsibilities which should be shouldered by developers, nongovernment safety personnel, and consultants [5].

Zeng et al., [6] discussed factors which affected safety in the construction industry in China. Their research methods consisted of a structured questionnaire survey and interviews. The questionnaires were sent to safety representatives of Chinese construction firms, whereas the interviews were conducted with Chinese government officials in charge of safety. The main factors affecting safety performance in China were identified as poor safety awareness of top management, lack of training, poor safety awareness of project managers, reluctance to input resources ensuring safety, and reckless operation. Kartam et al., [7] evaluated existing safety regulations and procedures adopted by owners, designers, contractors, and insurance companies in Kuwait. Different research activities, such as field visits, questionnaires and interviews, were used to collect the necessary information and data. The factors which contribute to poor safety standards were compiled as disorganized labour, poor accident record keeping and reporting systems, extensive use of foreign labour, extensive use of sub-contractors, lack of safety regulations and legislation, low priority given to safety, the small size of most construction firms, competitive tendering, and severe weather conditions during summers.

The wage trend in the construction industry from 1880 to 2004 varies from i) Yearly -0.24 to 76.40 ii) Monthly -7.08 to 2292.00 , iii) Daily -85.00 to 27504 . Construction man power in India between 1995 and 2007 has shown an annual increase from $9.33 \%$ to $11.09 \%$.

Okoye et al., [8] examined the health and safety knowledge and compliance of building construction workers on site in Anambra State, Nigeria. Questionnaires containing information relating to health and safety at the site were administered randomly to the construction workers and it was found that the level of health and safety knowledge among the construction workers in the state was moderate. Knowledge and compliance alone are not enough to cause behavioural changes required for adequate safety, but certain aspects of safety culture are required. These other essential safety factors include: enforceable regulatory framework, management commitment, and worker involvement, which must also be considered for improved project performance. Musonda \& Smallwood [9] revealed that the level of H\&S awareness is low, H\&S legislation is not complied with, the management of contractors is not committed to $H \& S$ implementation, there is a lack of H\&S management systems, procedures, and protocol, and clients and designers do not participate in the implementation of H\&S. 
Ashly Babu [10] investigated safety performance on construction sites. The data was collected from the contractors, consultants, and owners by using a questionnaire to evaluate the safety performance on the construction sites. The results show that there was still a lack of commitment from the government, the insurance company, the labour ministry, the owners, consultants, and also the contractors to improve safety performance on the sites. Romel and Ricardo [11] explored workers' perceptions of safety practices in their habitual work environment and concluded that the workers have received very little education and possess a limited culture of safety awareness, which has led them to perceive that their lack of precaution is the main cause of accidents. A proper coordination between contractors, clients, and the workforce is needed for safe work conditions which are very much lacking in Indian construction companies. Though labour safety laws are in place, the numerous accidents occuring at construction sites continue [12].

\section{THE BOCW ACT, 1996}

There is an exception for residential houses for private purposes constructed with a cost not exceeding 10 lakh and other activities to which the provisions of the Factories Act of 1948 and the Mines Act of 1952 apply. It applies to every establishment which employs or had employed on any day of the preceding 12 months 10 or more building workers in any building or other construction work [13, 14].

Provision for Health \& Safety measures for construction workers are made in conformity with ILO convention No.167 concerning Safety \& Health in construction. For this purpose comprehensive Central Rules have been notified by the Central Government (1998). Article 18 requires that in respect of work at height exceeding the allowed limit, prevention measures are to be taken against the fall of the workers, tools, materials and other objects and precautions against inadvertent stepping on or falling through fragile materials.

The major provisions include i) constitution of advisory committees (at the central and state level) ii) registration of establishments, iii) registration of workers as beneficiaries (under the welfare board) iv) constitution of welfare boards at the state level, v) safety and health measures vi) welfare measures. provisions for immediate assistance by the board are given in case of: i) accidents ii) senior pension iii) loans for construction of house, iv) premium for group insurance, v) financial assistance for education, vi) to meet medical expense, vii) maternity benefits, etc. 
To raise the funds for provisions of various welfare measures, the main act provides for the constitution of welfare boards. A major source of funds shall be the collection of tax at rates not exceeding $2 \%$ of the total cost of construction incurred by an employer. Collection of funds and administration of the welfare boards are the responsibilities of the appropriate state governments $[15,16,17]$.

\section{SAFETY PROVISIONS}

\subsection{EXCESSIVE NOISE (Rule 34)}

The permissible noise levels for different times of exposure are presented in Table 1.

Table 1 - Permissible Noise Levels

\begin{tabular}{|c|c|}
\hline Total time of exposure per day (in hours) & Noise level in dBA \\
\hline 8 & 90 \\
\hline 6 & 92 \\
\hline 4 & 95 \\
\hline 3 & 97 \\
\hline 2 & 100 \\
\hline 1 & 105 \\
\hline $3 / 4$ & 107 \\
\hline $1 / 2$ & 110 \\
\hline $1 / 4$ & 115 \\
\hline
\end{tabular}

\subsection{Fire Protection (Rule 35)}

An employer shall ensure:

- Fire extinguishing equipment sufficient to extinguish any possible fire at such construction sites.

- Adequate water supply at ample pressure as per national standards

- Number of trained persons for the operation of the fire extinguishing equipment 
- Maintenance and inspection regularly and not less than once a year by responsible person

- Provision of fire extinguishing equipment in a launch or boat for the transportation of workers $\&$ cabin of lifting appliances and mobile crane

\subsection{EMERGENCY ACTiOn Plans (Rule 36)}

Emergency action plans for construction establishments employing more than 500 building workers shall prepare emergency action plans for the following emergencies:

- fires and explosions

- collapse of lifting appliances \& transport equipment

- collapse of buildings, sheds, or structures, etc

- gas leakages and spillage of dangerous goods or chemicals

- drowning of building workers, sinking of vessels

- landslides getting building workers buried storms and other natural calamities

\subsection{LifTing \& CARRYing OF EXCESSIVE Weight (Rule 38)}

No building worker lifts by hand or carries over his head, back or shoulders any material, article, tool, or appliance exceeding weight limits set per Table 2.

Table 2 - Permissible Load

\begin{tabular}{|l|c|}
\hline \multicolumn{1}{|c|}{ Persons } & Maximum wt. load \\
\hline (a) Adult man & 55 Kilograms \\
\hline (b) Adult woman & 30 Kilograms \\
\hline (c) Adolescent male & 30 Kilograms \\
\hline (d) Adolescent female & 20 Kilograms \\
\hline
\end{tabular}




\subsection{Health \& Safety Policy (Rule 39)}

The Health \& Safety policy should be prepared by establishments employing 50 or more building workers \& submit it to director general for approval.

\subsection{DANGerous \& Harmful EnVironment (Rule 40)}

a) Adequate \& suitable measures by employer to keep atmospheric CO content below $50 \mathrm{ppm}$.

b) No permission for workers to enter confined spaces, tanks, trenched or excavation sites until precautions have been taken and certification issued by responsible party.

Similarly, provisions are given for over head protection (rule 41), electrical hazards (rule 47), stability of structures (rule 49), test \& periodical examination of lifting appliances (rule 56) and lifting gear (rule 70), operator's cabin (rule 63), transport and earth moving equipment (rule 88 to 95), concrete work (rule 96 to 107), demolition (rule 108 to 118), demolition of walls, partition, etc. (rule 110), inspection (rule 116), warnings signs and barricades (rule 117), mechanical method of demolition (rule 118), construction, repair \& maintenance of steep roof (rule 169 - 171), ladders \& step ladders (rule 172 to 174 ), catch platform $\&$ hoardings, chutes, safety belts $\&$ nets (rule 175 to 180 ), safety belt, safety net (rule 178 to 180), safety officer (rule 209), hazardous process (rule 225), notifiable occupational diseases (rule 230), hazardous processes (Schedule IX).

\section{CONCLUSION}

The statutory provisions on construction safety are aimed at providing occupational safety and health to construction workers to protect them from the hazards at construction sites. The statutory provisions also provides for data collection regarding accidents aimed at fixing responsibility and implementing corrective actions. Most of the states have started implementing the BOCW Act and Rules in their respective states by enacting state rules. The enforcement of safety provisions on construction sites will go a long way in protecting construction workers from occupational hazards. It is imperative on the part of all the stack holders to contribute towards ensuring safety of construction workers by the effective implementation of the statutory provisions. 


\section{REFERENCES}

1. Charles Chiocha, John Smallwood, Fidelis Emuze, Health and safety in the Malawian construction industry, Acta Structilia, 2011; 18(1).

2. Kanchana S., Sivaprakash P., A Review on Challenges in Implementation of Total Quality Management in Construction Firms, International Journal of Research in Management Sciences, 2014; 2(2); 47-54.

3. A.J. Jeya Arthi, A.Hemamalinie, Dr L.Ramajeyam, Applicable Legal Requirements in a Construction Site, International Journal of Emerging Technology and Advanced Engineering, 2014; 4(4);55-59.

4. David M. Zalk, Ton Spee, Matt Gillen, Thomas J. Lentz, Andrew Garrod, Paul Evans, Paul Swuste, Review of Qualitative Approaches for the Construction Industry: Designing a Risk Management Toolbox, Safety and Health at Work, 2011;2(2); 105-121.

5. Charles Y.J. Cheah, Construction Safety and Health Factors at the Industry Level: The Case of Singapore, Journal of Construction in Developing Countries, 2007; 12(2); pp.81-99.

6. Zeng, S.X., Tam, C.M. and Deng, Z.M., Identifying elements of poor construction safety management in China. Safety Science, 2004; 42(7); 569-586.

7. N.A. Kartam, I. Flood, P. Koushki, Construction safety in Kuwait: issues, procedures, problems, and recommendations, Safety Science, 2000; 36; 163-184.

8. Peter Uchenna Okoye, John Ugochukwu Ezeokonkwo, Fidelis Okechukwu Ezeokoli, Building Construction Workers' Health and Safety Knowledge and Compliance on Site, Journal of Safety Engineering, 2016; 5(1),17-26.

9. Innocent Musonda, John Smallwood, Health and safety (H\&S) awareness and implementation in Botswana's construction industry, Journal of Engineering, Design and Technology, 2008; 6(1);81-90.

10. Ashly Babu, Assessment of Safety Practices in Construction Industry, International Journal on Engineering Technology and Sciences, 2015; 2(5); 89-95.

11. Romel G. Solis Carcano, Ricardo J. Franco Poot, Construction Workers' Perceptions of Safety Practices: A Case Study in Mexico, Journal of Building Construction and Planning Research, 2014; 2; 1 - 11.

12. Kanchana S., Sivaprakash P., Sebastian Joseph, Study on Labour Safety in Construction Sites, The Scientific World Journal, 2015; 2015 (2015); 1-6.

13. The Building and other Construction Workers (Regulation of Employment and Conditions of Service) Act, 1996.

14. The Building and Other Construction Workers' (Regulation of Employment and Conditions of Service) Central Rules, 1998.

15. The TamilNadu Building and Other Construction Workers' (Regulation of Employment and Conditions of Service) Rules, 2000.

16. The Building and Other Construction Workers' Welfare Cess Act, 1996.

17. The Building and Other Construction Workers' Welfare Cess Rules, 1998. 


\section{LIST OF TABLES:}

Tab. 1. Permissible Noise Levels

Tab. 1. Dopuszczalny poziom hałasu

Tab. 2. Permissible Load

Tab. 2. Dopuszczalne obciążenie

Received 26.11.2017

Revised 10.04.2018

\section{ANALIZA PRZEPISÓW BEZPIECZEŃSTWA W BUDOWNICTWIE W INDIACH}

Slowa kluczowe: Ustawa $\mathrm{BOCW}^{1}$, bezpieczeństwo w budownictwie, ryzyko, ustawodawstwo

\section{STRESZCZENIE:}

Pracownicy budowlani stanowią duży odsetek niezorganizowanej siły roboczej. W Indiach istnieje wiele przepisów prawnych zapewniających bezpieczeństwo pracownikom kontraktowym. Sektor budownictwa wiąże się z dużym zapotrzebowaniem na siłę roboczą i uwzględniając pośrednie miejsca pracy, zatrudnia ponad 35 milionów ludzi. Praktyki zarządzania zdrowiem i bezpieczeństwem w procesie budowlanym mogą być świadczone na różnych etapach zatrudnienia. Wysoce niezadowalający jest fakt, że wdrożenie przepisów dotyczących zdrowia i bezpieczeństwa w budownictwie nie przyniosło żadnej poprawy. W opracowaniu zostały omówione różne przepisy dotyczące bezpieczeństwa w budownictwie w Indiach. Wejście w życie przepisów dotyczących bezpieczeństwa w budownictwie znacznie przyczyni się do ochrony pracowników budowlanych przed zagrożeniami o charakterze zawodowym.

\footnotetext{
${ }^{1}$ Ustawa dotycząca pracowników budowlanych - przyp. thum.
} 